Дитяча стоматологія

удК 616.314-002-036.111:(616.314.13+616.314-083)]-083)]-053.6

DOI 10.11603/2311-9624.2018.2.8455

(С). О. Шпотюк

Львівський національний медичний університет імені Данила Галицького

\title{
Взаємозв'язок між інтенсивністю карієсу, структурно- функціональною резистентністю емалі та гігієною порожнини рота у дітей із карієсом оклюзійної поверхні жувальної групи зубів
}

Резюме. У статті описано взаємозв'язок між інтенсивністю карієсу, гігієною порожнини рота та резистентністю емалі в період вторинної мінералізації зубів, що є сьогодні актуальним завданням, вирішення якого стане основою обгрунтування профілактики карієсу.

Мета дослідження - оцінити взаємозв'язок між інтенсивністю карієсу, гігієною порожнини рота та резистентністю емалі у період вторинної мінералізації зубів.

Матеріали і методи. Обстежено 156 дітей, серед них 76 осіб віком від 12 до 15 та 80 - від 16 до 18 років. Щоб оцінити ураження жувальних зубів карієсом, визначали інтенсивність за індексом КПВ та рівні інтенсивності за критеріями ВОО3. Стан гігієни порожнини рота оцінювали за допомогою гігієнічного індексу Green-Vermilion. Структурно-функціональну резистентність визначали за ТЕР-тестом В. Р. Окушко й Л. І. Косаревої (1983).

Результати досліджень та їх обговорення. У результаті проведених досліджень ми встановили, що зі збільшенням інтенсивності каріозного процесу в дітей обох груп погіршується гігієнічний стан ротової порожнини відповідно до даних індексу OHI-S. Також між цим індексом і TEP-тестом існує сильний прямий кореляційний зв’язок. При збільшенні ТЕР-тесту підвищується значення індексу OHI-S.

Висновки. Незадовільний рівень гігієни порожнини рота, особливо в період активної мінералізації емалі, сприяє зниженню резистентності емалі, що і відіграє значну роль у комплексі розвитку карієсу в дітей груп дослідження.

Ключові слова: гігієна; інтенсивність карієсу; структурно-функціональна резистентність; оклюзійний карієс.

\section{(С). О. Шпотюк}

Львовский национальный медицинский университет имени Данила Галицкого

\section{Взаимосвязь между интенсивностью кариеса, структурно- функциональной резистентностью эмали и гигиеной полости рта у детей с кариесом окклюзионной поверхности жевательной группы зубов}

Резюме. В статье описано взаимосвязь между интенсивностью кариеса, гигиеной полости рта и резистентностью эмали в период вторичной минерализации зубов, что является на сегодняшний день актуальной задачей, решение которой станет основой обоснования профилактики кариеса.

Цель исследования - оценить взаимосвязь между интенсивностью кариеса, гигиеной полости рта и резистентностью эмали в период вторичной минерализации зубов.

Материалы и методы. Обследовано 156 детей, среди них 76 лиц в возрасте от 12 до 15 и 80 - от 16 до 18 лет. Чтобы оценить пораженность жевательных зубов кариесом, определяли интенсивность по индексу КПУ и уровне интенсивности по критериям ВООЗ. Состояние гигиены полости рта оценивали с помощью гигиенического индекса Green-Vermilion. Структурно-функциональную резистентность определяли ТЭР-тестом В. Р. Окушко и Л. И. Косаревои (1983).

Результаты исследований и их обсуждение. В результате проведенных исследований мы установили, что с увеличением интенсивности кариозного процесса в детей обеих групп ухудшается гигиеническое состояние полости рта по данным индекса OHI-S. Также между этим индексом и TЭР-тестом существует сильный прямой корреляционной связь. При увеличении ТЭР-теста повышается значение индекса OHI-S. 
Выводы. Неудовлетворительный уровень гигиены полости рта, особенно в период активной минерализации эмали, способствует снижению резистентности эмали, и играет значительную роль в комплексе развития кариеса у детей групп исследования.

Ключевые слова: гигиена; интенсивность кариеса; структурно-функциональная резистентность; окклюзионный кариес.

\section{CO. O. Shpotyuk}

Danylo Halytskyi Lviv National Medical University

\section{The relationship between the intensity of caries, the structural and functional resistance of enamel and oral hygiene in children with caries of the occlusal surface of the chewy group of teeth}

Summary. The article describes the relationship between caries intensity, oral hygiene and enamel resistance during the period of secondary mineralization of teeth is an actual task, the solution of which will be the basis for the justification of caries prevention.

The aim of the study - to assess the relationship between caries intensity, oral hygiene and enamel resistance during the period of secondary mineralization of the teeth.

Materials and Methods. 156 children were examined, among them 76 were between 12 and 15 years of age and 80 children aged 16 to 18 years. To assess the odor of caries of chewing teeth, the intensity of the KPV index and intensity levels according criteria were determined. The condition of hygiene of the oral cavity was estimated using the hygienic index Green-Vermilion. Structural-functional resistance was determined by the TER-test Okushko V. R., Kosareva L. I. (1983).

Results and Discussion. As a result of our research, we found that with an increase in the intensity of the carious process in children of both groups of the study deterioration of the hygienic state of the oral cavity according to the OHI-S index. Also between this index and TER-test there is a strong correlation relationship. When TER-test increases the value of OHI-S index enlarges.

Conclusions. Unsatisfactory level of hygiene of the oral cavity, especially during the period of active mineralization of the enamel, contributes to reducing the resistance of the enamel, which plays a significant role in the development of caries in children of the study group.

Key words: hygiene; caries intensity; structural and functional resistance; occlusive caries.

Вступ. Недивлячись на значний розвиток у стоматології, в тому числі й дитячої, проблема карієсу в дітей залишається однією із актуальних. Клінічні спостереження, наукові дослідження свідчать про зростання ураження зубів карієсом у всіх вікових групах дітей [1, 2]. Значно частіше і раніше серед ураження різних груп зубів спостерігають оклюзійний карієс бічних зубів та його ускладнення. Водночас, результати досліджень свідчать, що впровадження ефективних профілактичних заходів на індивідивідуальному та масовому рівнях сприяють стабілізації або значному зниженню до мінімальних значень, інтенсивності карієсу зубів [3-7].

Встановлено, що значний вплив на розвиток карієсу зубів має гігієнічний догляд за порожниною рота [8, 9]. Незадовільний стан гігієни ротової порожнини сприяє порушенню процесів вторинної мінералізації та формуванню карієссприятливої емалі. Тому важливо при проведенні профілактичних заходів у дітей оці- нювати не лише стан гігієни порожнини рота, a і резистентність емалі. У зв'язку з цим, дослідження взаємозв'язку між інтенсивністю карієсу, гігієною порожнини рота та резистентністю емалі в період вторинної мінералізації зубів $є$ актуальним завданням, вирішення якого стане основою обгрунтування профілактики карієсу.

Мета дослідження - оцінити взаємозв'язок між інтенсивністю карієсу, гігієною порожнини рота та резистентністю емалі у період вторинної мінералізації зубів.

Матеріали і методи. Обстежено 156 дітей, серед них 76 осіб віком від 12 до 15 та 80 - від 16 до 18 років. Щоб оцінити ураження жувальних зубів карієсом, визначали інтенсивність за індексом КПВ та рівні інтенсивності за критеріями В003. Стан гігієни порожнини рота оцінювали за допомогою гігієнічного індексу Green-Vermilion. Структурно-функціональну резистентність визначали за ТЕР-тестом В. Р. Окушко, Л. І. Косаревої (1983). 


\section{Дитяча стоматологія}

Результати експериментальних досліджень проаналізовано за допомогою методу варіаційної статистики в парному двовибірковому тесті для середніх значень за програмами Statistica Basic прикладного пакета Statistica для Windows (версія 6.0). Первинну статистичну обробку даних проводили з обчисленням середньої арифметичної (М), середнього квадратичного відхилення, середньої похибки середнього арифметичного - похибки репрезентативності (м), аналізом середніх значень за t-критерієм Стьюдента. Статистичну достовірність відмінностей середніх значень визначали за співвідношенням ймовірності випадковості (р) до 0,05.

Результати досліджень та їх обговорення. Результати обстеження дітей показали, що в середньому частота оклюзійного карієсу жувальних зубів у дітей 12-15 років складає $(92,22 \pm 3,68) \%$ при КПВ $=(4,38 \pm 0,03)$ зуба, а у дітей $16-18$ років відповідно $(95,72 \pm 3,68) \%$ і
КПВ $=(4,20 \pm 0,03)$ зуба. При аналізі рівнів інтенсивності карієсу в дітей виявлено, що серед 12-15-річних частіше буває низький рівень інтенсивності карієсу (40,79 \%), а серед дітей 16-18 років - середній рівень (52,50 \%). Визначено значне зростання ураження карієсом оклюзійної поверхні зубів у 12-15-річних дітей із середнім рівнем інтенсивності $34,21 \%$ проти 18,49 \% у дітей із дуже низьким рівнем, $\mathrm{p}<0,01$, а в осіб $16-18$ років відповідно $52,50 \%$ проти 7,50 \%, p<0,01(рис. 1).

Структурно-функціональна резистентність емалі у дітей 12-15 років становить у середньому $(4,38 \pm 0,03)$ бала, а у $16-18$-річних дещо нижче і складає $\left(4,20 \pm 0,03, \mathrm{p}_{1}<0,01\right)$. Тобто у дітей віком 12-18 років резистентність емалі відповідає критеріям умовно резистентної. Встановлено, що 3 низьким рівнем інтенсивності карієсу структурно-функціональна резистентність емалі в середньому становить у $12-15$-річних дітей $(3,75 \pm 0,03)$ бала (рис. 2$)$, що

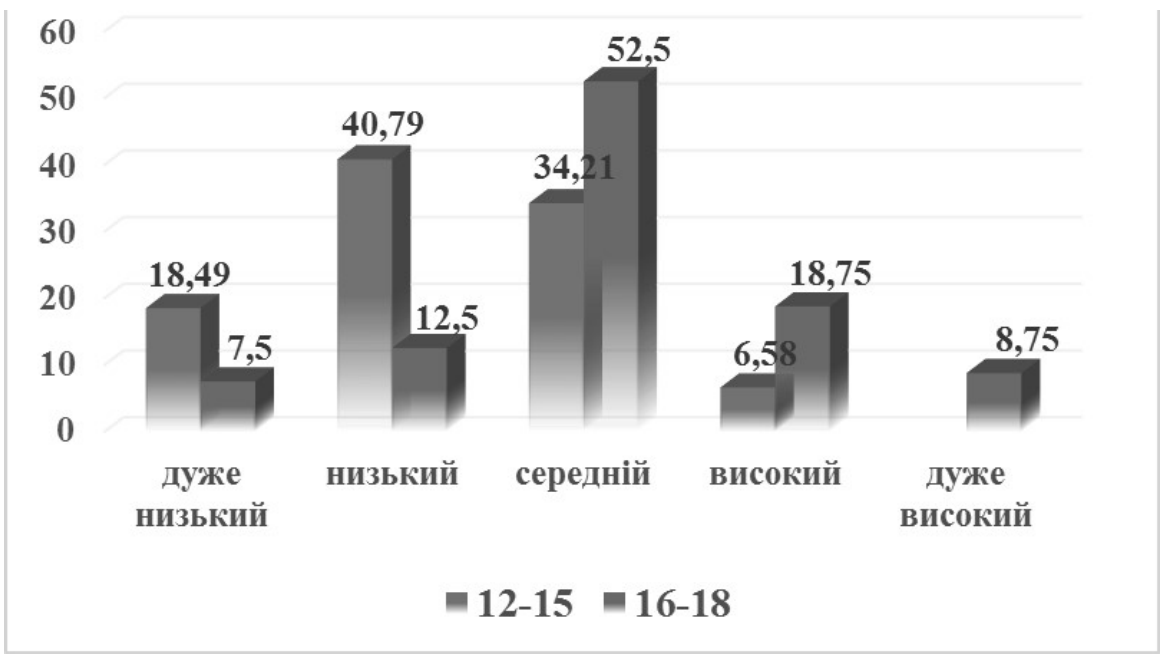

Puc. 1. Рівні інтенсивності карієсу зубів у 12-15 та 16-18-річних дітей (\%).

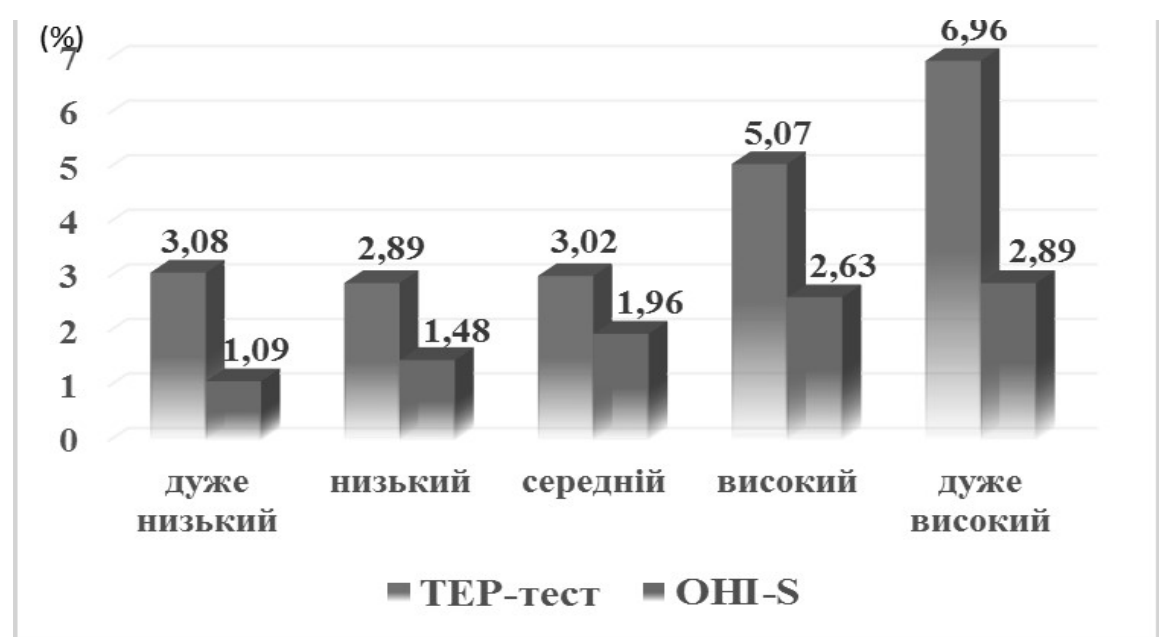

Puc. 2. Значення ТЕР-тесту (бали) та індексу гігієни порожнини рота (бали) в 12-15-річних дітей залежно від рівнів інтенсивності карієсу (\%). 
відповідає умовно резистентній емалі, а 16-18 років складає $(3,08 \pm 0,04)$ бала, $\mathrm{p}_{1}<0,01$, що відповідає карієсрезистентній емалі (рис. 3). При високих рівнях інтенсивності карієсу в дітей 16-18 років значення ТЕР-тесту зростає до $(6,96 \pm 0,03)$ бала, $\mathrm{p}_{1}<0,01$, що відповідає карієссприйнятливій емалі.

У результаті проведених досліджень ми встановили, що зі збільшенням інтенсивності каріозного процесу в дітей обох груп дослідження погіршується гігієнічний стан ротової порожнини згідно 3 даними індексу OHI-S. У дітей 12-15 років середнє значення індексу гігієни складає $(1,22 \pm 0,02)$ бала, що відповідає оцінці задовільної гігієни порожнини рота, та було у 1,6 раза менше стосовно даних у 16-18-річних дітей - $(2,01 \pm 0,04)$ бала, $\mathrm{p}_{1}<0,01$, що за критеріями індексу свідчить про незадовільну гігієну ротової порожнини. Необхідно зазначити, що у дітей у віці 12-15 років при дуже низькій та середній інтенсивності карієсу дані індексу гігієни становили $(1,68 \pm 0,78)$ бала та відповідали задовільному гігієнічному стану ротової порожнини, а при високому рівні інтенсивності карієсу індекс OHI-S зі значенням $(2,25 \pm 0,03)$ бала свідчив про незадовільний стан ротової порожнини обстежуваних. У дітей віком 16-18 років задовільний стан ротової порожнини був лише при дуже низькій та низькій інтенсивності карієсу $((1,09 \pm 0,02)$ бала та $(1,48 \pm 0,03)$ бала).

Встановлено, що у дітей віком 12-15 років між індексом OHI-S індексом та TEP-тестом існує достовірний $(\mathrm{p}<0,05)$ сильний прямий кореляційний зв'язок $(\mathrm{r}=+0,72)$. Це означає, що при збільшенні ТЕР-тесту зростає значення індексу OHI-S (рис. 4).

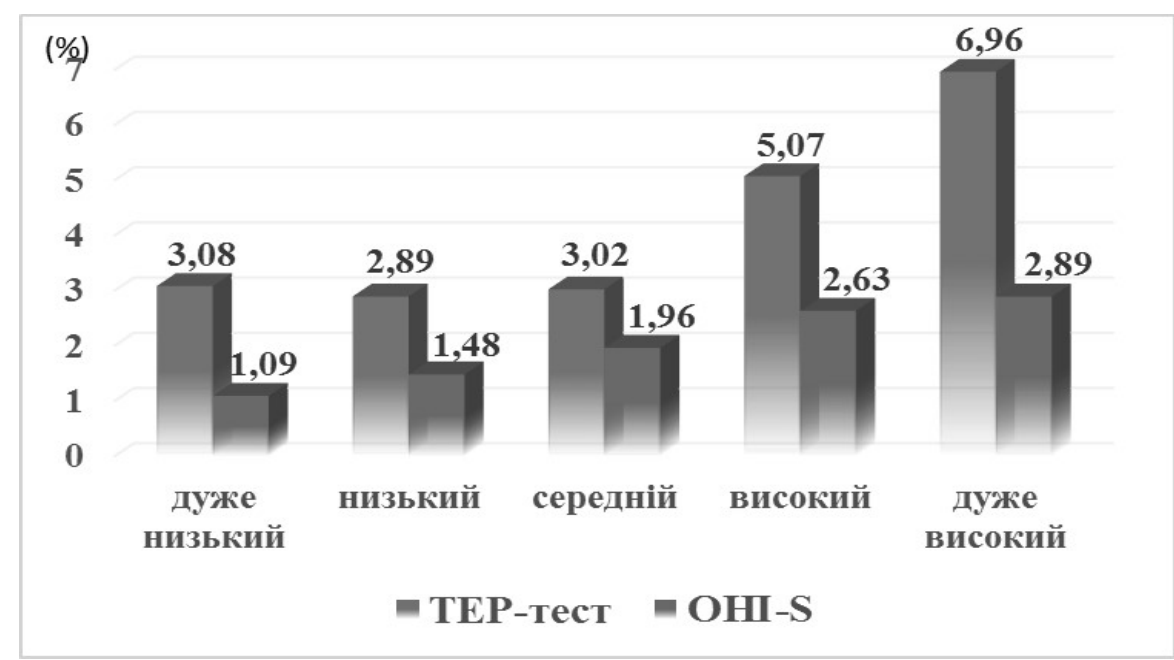

Puc. 3. Значення ТЕР-тесту (бали) та індексу гігієни порожнини рота (бали) у 16-18-річних дітей залежно від рівнів інтенсивності карієсу.

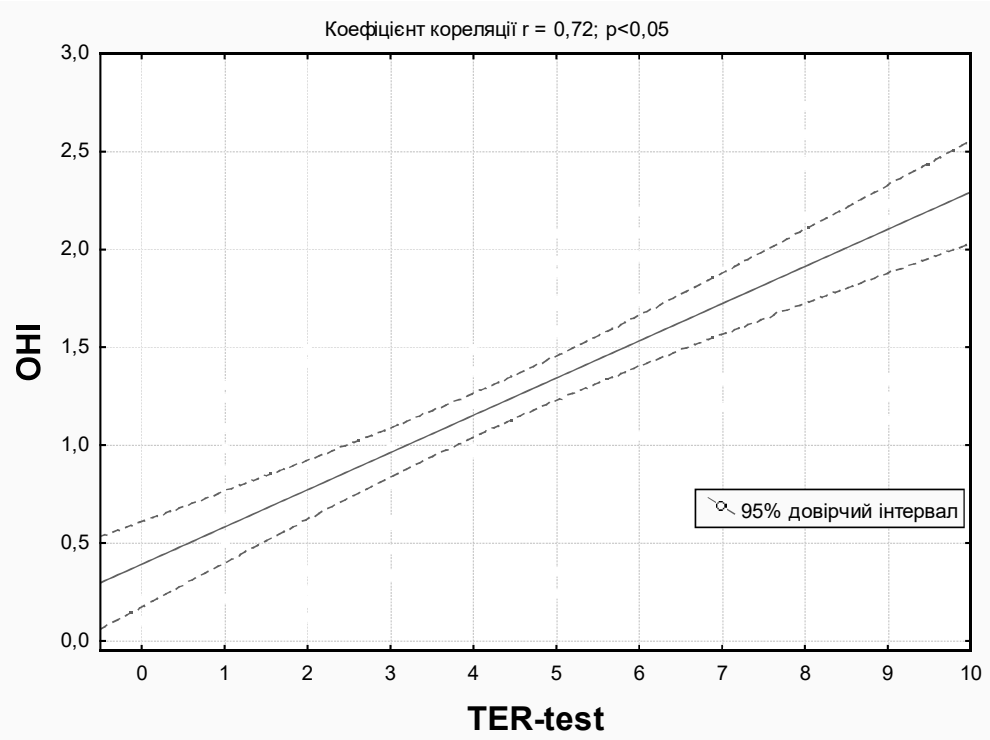

Puc. 4. Взаємозв’язок між індексом ОНI-S та ТЕР-тестом у 12-15-річних дітей. 


\section{Дитяча стоматологія}

Аналогічно з'ясовано, що у дітей віком 16-18 років між індексом OHI-S та TEP-тестом існує також достовірний $(\mathrm{p}<0,05)$ сильний прямий кореляційний зв’язок (r=+0,78). Це означає, що при збільшенні ТЕР-тесту зростає значення індексу OHI-S (рис. 5).

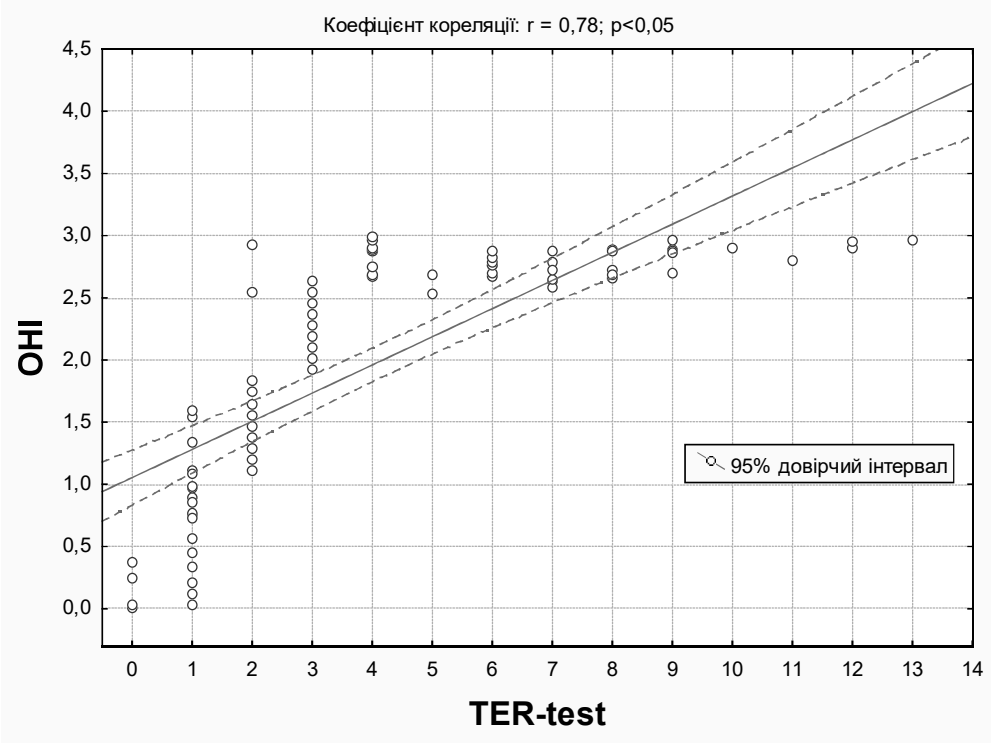

Puc. 5. Взаємозв’язок між індесом ОНI-S та ТЕР-тестом у 16-18-річних дітей.

Висновки. Результати дослідження підтверджують, що незадовільний стан гігієни порожнини рота, особливо в період активної мінералізації емалі, сприяє зниженню резистентності емалі, що і відіграє в комплексі зна- чну роль у розвитку карієсу. Окрім того, ці дані свідчать, що при застосуванні екзогенних засобів профілактики, спрямованих на підвищення резистентності емалі, необхідно проводити професійну гігієну порожнини рота.

\section{Список літератури}

1. Смоляр Н. І. Ураженість карієсом тимчасових зубів у дітей дошкільного віку м. Львова / Н. І. Смоляр, I. С. Дубецька // Укр. стоматол. альм. - 2004. - № 3-4. - С. 68-71.

2. Хоменко Л. О. Визначення значущості індикаторів ризику при різних рівнях інтенсивності карієсу зубів у дітей шкільного віку / Л. О. Хоменко, П. А. Леус, О. І. Остапко // Віс. соц. гігієни та організ. охорони здоров’я України. - 2016. - № 2 (68). C. $39-45$.

3. Безвушко Е. В. Профілактика карієсу перших постійних молярів у дітей на індивідуальному рівні / Е. В. Безвушко // Новини стоматології. - 2009. - № 2 (59). - С. 67-71.

4. Кравець Т. П. Гігієнічне навчання і виховання населення: основні аспекти / Т. П. Кравець // Профілакт. та дит. стоматол. - 2010. - № 2. - С. 48-52.

5. Кузьміна В. А. Обгрунтування схеми профілактики раннього дитячого карієсу / В. А. Кузьміна, Т. О. Якубова, О. С. Бучинська // Профілактична та

\section{References}

1. Smoliar, N.I., \& Dubetska, I.S. (2004). Urazhenist kariiesom tymchasovykh zubiv u ditei doshkilnoho viku mista Lvova [Defeat of caries of temporary teeth in children of preschool age in the city of Lviv]. Ukrainskyi дитяча стоматологія. - 2017. - № 2. - С. 39-41.

6. Кисельникова Л. П. Роль гигиены полости рта в профилактике стоматологических заболеваний у детей школьного возраста / Л. П. Кисельникова, Е. Н. Таболова, М. В. Мирошкина // Стоматол. для всех. - 2008. - № 1. - С. 52-56.

7. Кулигіна В. М. Динаміка змін показників біофізичного дослідження ротової рідини та рівня гігієни порожнини рота у підлітків з множинним карієсом зубів після лікування та проведення вторинної профілактики / В. М. Кулигіна, Л. Ф. Курдиш // Соврем. стоматол. - 2010. - № 4. - С. 162-164.

8. Назарян Р. С. Досвід підвищення резистентності емалі та застосування оптимізованої методики професійної гігієни порожнини рота / Р. С. Назарян, Л. С. Кривенко // Укр. стоматол. альманах. - 2013. № 6. - С. 33-35.

9. Гладка О. М. Вплив карієспрофілактичних засобів на резистентність емалі / О. М. Гладка // Стоматол. альманах. - 2013. - № 6. - С. 18-20.

stomatolohichnyi almanakh - Ukrainian Dental Almanac, 3, 68-71 [in Ukrainian].

2. Khomenko, L.O., Leus, P.A., \& Ostapko, O.I. (2016). Vyznachennia znachushchosti indykatoriv ryzyku pry 
riznykh rivniakh intensyvnosti kariiesu zubiv u ditei shkilnoho viku [Determination of the significance of risk indicators at different levels of dental caries intensity in school-age children]. Visnyk sotsialnoi hihiieny ta orhaniv okhorony zdorovia Ukrainy - Bulletin of Social Hygiene and Authorities of Public Health of Ukraine, 2, 39-45 [in Ukrainian].

3. Bezvushko, E.V. (2009). Profilaktyka kariiesu pershykh postiinykh moliariv $\mathrm{u}$ ditei na indyvidualnomu rivni [Prevention of caries of the first permanent molars in children of the individual level]. Novyny stomatolohii Dental News, 2 (59), 67-71 [in Ukrainian].

4. Kravets, T.P. (2010). Hihiienichne navchannia i vykhovannia naselennia: osnovni aspekty [Hygienic education and education of the population]. Profilaktychna ta dytiacha stomatolohiia - Profilactic and Child Dentistry, 2, 48-52 [in Ukrainian].

5. Kuzmina, V.A., Yakubova, V.A., \& Buchynska, O.S. (2017). Obhruntuvannia skhemy profilaktyky rannoho dytiachoho kariiesu [Justification of the scheme of prevention of early childhood caries]. Profilaktychna ta dytiacha stomatolohiia - Preventive and Pediatric Dentistry, 2, 39-41 [in Ukrainian].

6. Kiselnikova, L.P., Tabolova, M.V., \& Miroshkina E.N. (2008) Rol gigiyeny polosti rta V profilaktike stomatologicheskikh zabolevaniy $\mathrm{u}$ detey shkolnogo vozrasta [The role of oral hygiene in preventing den- tal diseases in school-age children]. Stomatologiya dlya vsekh - Dentistry for Everyone, 1, 52-56 [in Russian].

7. Kulyhina, V.M., \& Kurdysh, L.F. (2010). Dynamika zmin pokaznykiv biofizychnoho doslidzhennia rotovoi ridyny ta rivnia hihiieny porozhnyny rota $u$ pidlitkiv z mnozhynnym kariiesom zubiv pislia likuvannia ta provedennia vtorynnoi profilaktyky [Dynamics of changes of indicators of biophysical study of oral fluid and lescents with multiple dental caries after treatment and secondary prevention]. Sovremennaya stomatologiya Modern Dentistry, 4, 162-164 [in Ukrainian].

8. Nazarian, R.S., \& Kryvenko, L.S. (2013). Dosvid pidvyshchennia rezystentnosti emali ta zastosuvannia optymizovanoi metodyky profesiinoi hihiieny porozhnyny rota [The experience of increasing the resistance of the enamel and the application of optimized methods of professional hygiene of the oral cavity]. Ukrainskyi stomatolohichnyi almanakh - Ukrainian Dental Almanac, 6, 33-35 [in Ukrainian].

9. Hladka, O.M. (2013). Vplyv kariies profilaktychnykh zasobiv na rezystentnist emali [The influence of caries prophylactic agents on the resistance of the enamel]. Stomatolohichnyi almanakh - Dental Almanac, 6, 18-20 [in Ukrainian].

Отримано 02.04.18 